\title{
Transformational, Transactional or Laissez-Faire: What Styles do University Librarians Practice?
}

\author{
Nor Famiza Tarsik ${ }^{1}$, Norliya Ahmad Kassim ${ }^{2}$ and Nurhidayah Nasharudin ${ }^{1}$ \\ ${ }^{1}$ Faculty of Information Management, Universiti Teknologi MARA Cawangan Kelantan, Bukit IImu, \\ 18500 Machang, Kelantan, Malaysia \\ ${ }^{2}$ Faculty of Information Management, Universiti Teknologi MARA (UiTM), Puncak Perdana Campus, \\ Shah Alam, Selangor, Malaysia
}

Correspondence should be addressed to: Nor Famiza Tarsik; norfamiza@kelantan.uitm.edu.my

Received 12 January 2013; Accepted 23 July 2013; Published 19 February 2014

Academic Editor: Roziah Mohd Rasdi

Copyright (C) 2014 Nor Famiza Tarsik, Norliya Ahmad Kassim and Nurhidayah Nasharudin.

Distributed under Creative Commons CC-BY 3.0

\begin{abstract}
The main objective of the study is to identify the leadership style that is being practiced by librarians in university libraries. In this quantitative study, questionnaire was used to collect data from 201 librarians of four universities in Malaysia. The results indicate that librarians are practising more on transformational leadership style $((\mathrm{M}=4.01)$ followed by laissez-faire leadership style $(M=3.73)$. Transactional leadership style $(M=3.67)$ is the least practised as compared to the transformational and laissez-faire leadership style. In addition, transactional leadership style showed significant difference among age groups. The result further indicated that there were significant differences on transformational leadership and transactional leadership between levels of positions and working experience of respondents. The outcome of this study is expected to assist practitioners to recognise their styles of leadership and find other factors that can help them to engage with subordinates in the organisation.
\end{abstract}

Keywords: Leadership style, transformational leadership, transactional leadership and laissezfaire leadership.

\section{Introduction}

Generally, it is natural to form a group when people are working together for certain completions. Each group member plays their role and all members are affecting the activities of others in one-way or the other. Hence, leadership role ultimately develops within the group formally or informally. In addition, by practising within the formal group, it is having structured interaction and coordination among group members. Basically, it is the fundamental role of a leader to organise the activities, to motivate the group, to assign the task and finally achieve the goals of the organisation.

Cite this Article as: Nor Famiza Tarsik, Norliya Ahmad Kassim and Nurhidayah Nasharudin (2014), "Transformational, Transactional or Laissez-Faire: What Styles do University Librarians Practice?," Journal of Organizational Management Studies, Vol. 2014 (2014), Article ID 194100, DOI: $10.5171 / 2014.194100$ 
Judge, Bono, Ilies and Gerhardt (2002) state that skill also plays a vital role in determining leader effectiveness and that to be effective, leaders must behave differently in different situations. Meanwhile, Fairholm (2004) suggests that as people begin to think of visions and values as organisational attractors, it helps leaders to understand the power of vision and values in setting and altering organisational contexts and cultures.

Furthermore, leadership today faces a lot of challenge to maintain a strategic vision while coping with ubiquitous and advancement of technology, fluctuations in budget and staffing. Sometimes, librarians also need to face with conflicting, expectations and demand for access to information and services and myriad other issues. As far as pure traits are concerned, Baldoni (2000) defined leadership in terms of $\mathrm{L}$-listening and learning from others, $\mathrm{E}$ energising the organisation, A - acting for the benefit of everybody, D - development of themselves and others, E empowerment of others to lead and R recognition of achievement.

A theory by Dawson (2002) states that the typical value set of those who work in libraries are not compatible with managing people or managing physical resources such as budgets, or operating confidently in a political and business environment. Some blame the library qualification providers for not attracting the right people. Therefore, the problems of implementation become issues about how leaders influence change the course of events and overcome resistance in order to achieve organisation goals. In addition, leadership is crucial in implementing decisions successfully.

This study is important for many people and institutions. This study may help them to apply suitable leadership style in order to achieve goal of institutions. Furthermore, they may enhance the leadership theory in order to understand the style of leadership.

From all the above perspectives, this paper tries to explore the leadership styles of librarians in Malaysian university libraries. The research questions put forward are:

1. What are the types of leadership style do academic librarians practised in university libraries?

2. Are there differences in their leadership styles by gender, institution they work, age, position and working experience?

\section{Review of Literature}

Fatokun et al., (2010) mention that a leader is a person who takes the central role in interactions and who influences the behaviour of other members of the group. $\mathrm{He}$ is an individual who has authority over others and is responsible for guiding their actions. Leadership must be defined in terms of the ability to build and maintain a group that performs in doing decision making for organisation. Moreover, leaders should be evaluated in terms of the performance of the group over time and their leadership skills. The true leaders really know their responsibility to give order and engage with subordinates in order to adapt to situations. This means leaders are using the most appropriate style to suit the people and circumstances at particular time. In addition, Burns (1978) states that leadership is one of the most observed and least understood phenomena on earth. Bohn and Grafton (2002) presume that leadership means the way to create a clear vision, filling their subordinates with self-confidence, created through coordination and communication to detail.

Leadership seems to be an activity of a member who is a leader of the group to influence a group member to achieve its goals (Lussier \& Achua, 2007). Furthermore, leaders' responsibility is to ensure that their subordinates can achieve a high level of both effectiveness and efficiency. Leadership styles of leaders cover many areas of styles which are showing in good style or another one not so good styles. Frequently, the role of leadership is largely determined by the culture of the organisation. Furthermore, there is no one leadership style that is 
ideal for every situation since a leader may have knowledge and skills to act effectively in one situation but may not emerge as effectively in a different situation. In this study, there are three types of leadership styles to be focused namely:

\section{Transformational Leadership}

According to Jong and Hartog (2007); and Kent, Crotts and Aziz (2001), transformational leaders are able to stimulate followers to see problems in new ways and help them to develop their full potential and resulted in enhanced creativity of their followers. There are four characteristics under this leadership which are:

\section{- Charisma or Idealised Influence}

The leader behaves in admirable ways that cause followers to identify with the leader. Usually, charismatic leaders display convictions, take stands and appeal to followers on an emotional level.

\section{- Inspirational Motivation}

This component describes the degree to which the leader articulates a vision that is appealing and inspiring to subordinates.

\section{- Intellectual Stimulation}

This component is the degree to which the leader challenges assumptions, takes risks and solicits followers' ideas. Furthermore, leaders with this trait stimulate and encourage creativity in their followers.

\section{- Individualised Consideration or Individualised Attention}

This component shows the leader attends to each follower's needs, acts as a mentor or coach to the follower and listens to the follower's concerns and needs.

\section{Transactional Leadership}

According to Bass, Avolio, Jung and Berson (2003), this style is usually at the top of the leaders' functional specialty and has limited perspective to see that change is needed and what the consequences may be for continuing the same practises. In essence, leader- follower relationships are believed to be based on a series of transactions or bargains between leaders and followers. The two characteristics of transactional leadership are:

\section{- Contingent Reward}

This characteristic shows the style of leaders to connect the goal to rewards, clarify expectations and provide various kinds of rewards for successful performance.

\section{- Management by Exception}

This characteristic consists of two types which are passive leader and active leader.

\section{Laissez-Faire Leadership}

The laissez-faire leadership style is also known as the "hands-off" style. It is one in which the manager provides little or no direction and gives employees as much freedom as possible. Basically, this style looks simple and easy-going between leaders and subordinates.

Both transformational and transactional leadership styles have been found to be positively correlated with organisational outcomes in studies of various types of organisations (Snodgrass \& Schachar, 2008). Burns (1978) mentions that transactional leadership behaviours are found on an exchange process in which the leader provides rewards in return for the subordinate's effort. In essence, leaderfollower relationships are believed to be based on a series of transactions or bargains between leaders and followers. Most recent researches on the leadership style and organisational commitment (Marmaya, Torsiman \& Balakrishnan, 2011) show that transformational and transactional leadership have positive relationship with employees' organisational commitment while employees of Malaysian organisation are more influenced by transformational than transactional. Jalil (2011) mentions that in earlier stage, that is the sense of urgency, 
transformational leadership is significant to ensure the buy-in among the employees.

In contrast to transformational and transactional leadership styles, leaders who adopt the laissez-faire leadership style exercise little control over the followers and let the followers have freedom to carry out their assigned tasks without direct supervision (Wu \& Shiu, 2009). The laissez faire leader delegates decision-making to the group and agrees to abide by their resolutions.

\section{Materials and Methods}

The data was collected from four university libraries namely Universiti Teknologi MARA (UiTM), Universiti Putra Malaysia (UPM), Universiti Islam Antarabangsa (UIA), and Universiti Sains Malaysia (USM). UPM and USM were Research Universities which focused on research. UiTM and UIA were known as Comprehensive Universities which offered a variety of courses and fields of study. The population of librarians in the four universities were 201 librarians. A structured questionnaire was developed by adapting the Multifactor Leadership Questionnaire (MLQ) to obtain data for this study. Questionnaires were distributed to 201 librarians however only 81 questionnaires were returned.

In addition, data was analysed using the Statistical Product Services Solution. The data analysis involved computing descriptive statistics as frequencies and percentages for analysing characteristics of the subjects in order to provide a description of the sample from which data was collected such as descriptive information on age, gender, type of institutions, position and working experience. Mean ranking and standard deviation were performed to analyse the descriptive part of the analysis. For the inferential statistical analysis, KruskalWallis test, independent samples $t$ - test and Mann-Whitney $U$ test were employed.

\section{Results}

\section{Profile of Respondents}

Out of 81 respondents, majority (60 or $74.1 \%$ ) are female and 21 (25.9\%) are male. Respondents from UiTM made up slightly more than one-third (30 or $37 \%$ ) of the total respondents followed by UPM $(25$ or $30.9 \%$ ) and UIA (17 or $21.0 \%)$. Only 9 $(11.1 \%)$ of the respondents are from USM. The highest numbers ( 37 or $45.7 \%$ ) of the respondents are in the range of 25-30 years age group followed by those in the age group of $31-40$ years old (30 or $37.0 \%$ ). Only $14(17.3 \%)$ are in the age group of 41 50 years old. Majority ( 60 or $74.1 \%$ ) of the respondents are holding the S41 position while only 21 (25.9\%) constitutes others. The result reveals that slightly more than two-thirds (55 or $67.9 \%$ ) of the respondents have worked in a range of 10 years and below, while slightly less than one-third (26 or $32.1 \%$ ) have worked more than 11 years.

\section{Reliability and Normality Test}

Results of reliability test shows that the Cronbach's Alpha value of leadership styles which consist of transformational leadership style (0.884), transactional leadership style (0.774), laissez-faire leadership style (0.669) are greater than 0.6 , thus reliable.

The transformational leadership style score is greater than 0.05 therefore normality is assumed. The transformational leadership style score is $p$-value $=0.122>0.05$, is normally distributed. Therefore, the use of parametric test to compare the mean scores ( $t$-test) is justified. Meanwhile, the results of Shapiro-Wilk Test for normality of transactional and laissez-faire leadership styles show that the score is lower than 0.05 . The transactional leadership style score is $p$-value $=0.010<0.05$ and laissezfaire leadership style score is $p=0.011<$ 0.05 , therefore, both are assumed as not normal. 


\section{Descriptive Statistics of Leadership Styles}

The leadership scales are measured by these dimensions - transformational, transactional, and laissez-faire leadership styles. Leadership scale scores have a range possibility of 1 to 5 . A score of 1 indicates the style is not practised at all, and a 5 is a behaviour or style practised frequently, if not always. By convention, in a scale of 1 to 5 , a score of three (3) is always interpreted as neutral and these are arranged in descending order of the mean score.
Table 1 shows the mean values for all of the research variables are above the mid value which is 3.0, thus entailing that respondents have practised transformational leadership style $((\mathrm{M}=$ 4.01, SD = 0.42). On the other hand, transactional leadership style $(M=3.67, \mathrm{SD}$ $=0.46)$ is the least practised leadership style as compared to the transformational leadership style and laissez-faire leadership style (M = 3.73, $\mathrm{SD}=0.57)$.

Table 1: Mean Score of Variables

\begin{tabular}{|l|l|l|}
\hline Variables & Mean & Standard Deviation \\
\hline Leadership Styles & & \\
\hline $\begin{array}{l}\text { Transformational } \\
\text { Leadership }\end{array}$ & 4.01 & 0.41 \\
\hline Laissez-faire Leadership & 3.73 & 0.57 \\
\hline Transactional Leadership & 3.67 & 0.46 \\
\hline
\end{tabular}

\section{Differences in Leadership Styles between Respondents' Demographic Profiles}

\section{Difference between Genders}

To determine whether there is a difference regarding the three different leadership styles (transformational, transactional and laissez-faire) between genders, both independent samples $t$-test and the MannWhitney $U$ Test, which are tests of difference between average scores, are used. This is because the distribution of scores for transformational leadership style is normal and both transactional and laissez-faire leadership styles are not normal. Results of the statistical tests are presented in Table 2 and Table 3. It can be seen that in Table 2 the overall mean score of transformational leadership style for female group, at 4.04 , is higher than the male group which is 3.91 , but this apparent difference is statistically not significant at the $5 \%$ significance level ( $p$-value $>0.05$ ) Therefore, it is concluded that on the average, the transformational leadership style does not differ between male and female respondents.

Table 2: Summary Statistics of $t$-test on Transformational Leadership Style between Gender

\begin{tabular}{|l|l|l|l|l|l|}
\hline & Gender & $\mathrm{N}$ & Mean & Std. Deviation & $p$-value \\
\hline \multirow{2}{*}{ Transformational } & Female & 60 & 4.04 & 0.42 & 0.20 \\
\cline { 2 - 6 } & Male & 21 & 3.91 & 0.38 & \\
\hline
\end{tabular}

Table 3 shows the statistics of MannWhitney $U$ Test of both transactional and laissez-faire leadership styles between genders. The results of comparison as displayed in Table 3 show that there is significant difference ( $p$-value lower than the recommended 0.05 level, $p=0.049$ ) on the transactional leadership style with regard to gender. It can be seen that the overall mean score of transactional leadership style for female group, at 44.03, is higher than the male group's score of 41.01. Therefore, it is concluded that transactional leadership style differs 
between male and female respondents. Table 3 shows that there is no significant difference $(p=0.99>0.05)$ on laissez-faire between gender. Therefore, it is concluded that on the average, the laissez-faire leadership style is the same regardless of what gender they are.

Table 3: Summary Statistics of Mann-Whitney $U$ Test on Transactional Leadership Style and Laissez-faire Leadership Style between Gender

\begin{tabular}{|l|l|l|l|l|l|}
\hline Item & $\begin{array}{l}\text { Mean } \\
\text { Rank } \\
\text { (Female) }\end{array}$ & $\begin{array}{l}\text { Mean } \\
\text { Rank } \\
\text { (Male) }\end{array}$ & $\begin{array}{l}\text { Mann- } \\
\text { Whitney } \\
\boldsymbol{U}\end{array}$ & $\begin{array}{l}\text { Z- } \\
\text { value }\end{array}$ & $\begin{array}{l}\boldsymbol{p} \text { - } \\
\text { value }\end{array}$ \\
\hline Transactional & 44.03 & 32.36 & 448.500 & -1.970 & 0.049 \\
\hline Laissez-faire & 41.01 & 40.98 & 629.500 & -.005 & 0.99 \\
\hline
\end{tabular}

\section{Differences between Institutions}

A statistical test of significance is carried out using the independent samples $t$-test to compare the difference on transformational leadership style between institutions and the results are shown in Table 4. It can be seen that both focus university librarians and research university librarians give high ratings for the statements, with mean score of 4.01 respectively. This difference is statistically not significant at the $5 \%$ probability level $(p=1.000>0.05)$. Therefore, it is concluded that librarians from both institutions have a positive perception about the transformational leadership style.

Table 4: Summary Statistics of $t$-test on Transformational Leadership Style between Institutions

\begin{tabular}{|c|c|c|c|c|c|}
\hline & Institution & $\mathrm{N}$ & Mean & $\begin{array}{c}\text { Std. } \\
\text { Deviation }\end{array}$ & $\begin{array}{c}\text { Sig. (2- } \\
\text { tailed) }\end{array}$ \\
\hline Transformational & $\begin{array}{c}\text { Comprehensive } \\
\text { Universities }\end{array}$ & 47 & 4.01 & 0.49 & 1.000 \\
\cline { 2 - 6 } & $\begin{array}{c}\text { Research } \\
\text { Universities }\end{array}$ & 34 & 4.01 & 0.37 & \\
\hline
\end{tabular}

The results of the Mann-Whitney $U$ Test are presented in Table 5. It appears that respondents of focus university give a slightly higher mean score (more positive on transactional and laissez faire leadership style) than those from research university respondents, but this apparent difference is statistically not significant at the $5 \%$ significance level ( $p$-value $>0.05$ ). Therefore, it is concluded that on the average, the practise of leadership styles (transformational, transactional and laissez-faire leadership styles) do not differ between respondents of focus and research universities.

Table 5: Summary Statistics of Mann-Whitney $U$ Test on Transactional Leadership Style and Laissez-faire Leadership Style between Types of Institutions

\begin{tabular}{|c|c|c|c|c|c|}
\hline Item & $\begin{array}{c}\text { Mean Rank } \\
\text { (Comprehensive } \\
\text { University) }\end{array}$ & $\begin{array}{c}\text { Mean Rank } \\
\text { (Research } \\
\text { University) }\end{array}$ & $\begin{array}{c}\text { Mann- } \\
\text { Whitney } \boldsymbol{U}\end{array}$ & Z-value & $\boldsymbol{p}$-value \\
\hline Transactional & 42.01 & 39.60 & 751.500 & -.458 & 0.65 \\
\hline Laissez-faire & 42.44 & 39.01 & 731.500 & -.656 & 0.51 \\
\hline
\end{tabular}




\section{Differences between Age Groups}

The results show further that there is a significant difference regarding transformational leadership style among age groups. Table 6 presents the results of the comparison of means of transformational leadership style among age groups. The result shows that on the average, the transformational leadership style between the respondents from three different ages is statistically not significant ( $p$-value $>0.001)$. This indicates that the practise of transformational leadership style is the same regardless of which age groups the respondents belong.

Table 6: Summary Statistics of ANOVA between Age Group

Transformational Leadership Style

\begin{tabular}{|l|c|c|c|c|c|}
\hline & Sum of Squares & df & Mean Square & F & Sig. \\
\hline Between Groups & .667 & 2 & .333 & 2.003 & 0.142 \\
\hline Within Groups & 12.980 & 78 & .166 & & \\
\hline Total & 13.647 & 80 & & & \\
\hline
\end{tabular}

Summary Statistics of Kruskal-Wallis Test between Age Groups

\begin{tabular}{|c|c|c|}
\hline Test Statistics & Transactional & Laissez-faire \\
\hline Mean rank: $25-30$ & 34.08 & 43.93 \\
\hline Mean rank: $31-40$ & 45.03 & 38.43 \\
\hline Mean rank: above 41 & 50.64 & 38.75 \\
\hline Chi-Square & 0.53 & 1.10 \\
\hline$p$-value & 0.04 & 0.58 \\
\hline
\end{tabular}

The non-parametric statistical test used in this analysis is the Kruskal-Wallis Test which involved more than two groups of respondents. Table 6 presents the summary statistics. The Chi-Square value of practising transactional leadership style (0.53) is significant at $5 \%$ level ( $p=0.04<$ $0.05)$. It is concluded, therefore, that the practise of transactional leadership style among the respondents differ among the age groups.

In the case of practicing laissez-faire leadership style, the Chi-Square value, which is 1.092 , is not significant at $5 \%$ level ( $p=0.58>0.05$ ). It is concluded, therefore, the level of practicing laissez-faire leadership style is the same regardless of which age group the respondents belong.

\section{Differences between Positions}

Table 7 shows the statistics of the independent samples $t$-test on transformational leadership style between positions. Both positions of the respondents are the professional librarians who have at least one subordinate, hence, they are assumed as leaders and the respondents are all the librarians who have qualification in at least a Bachelor in Library Science and have experienced as a librarian. It can be seen that the overall mean score of transformational leadership style for S41 positions, at 3.93 is lower than the other position which is at 4.23 . These both differences are statistically significant at the $5 \%$ level ( $p$-value $<0.05$ ) as presented in Table 7. Therefore, it is concluded that on the average, the practise of transformational leadership style differs between respondents of S41 and S44-JUSA. 
Table 7: Summary Statistics of $t$-test Between on Transformational Leadership between Position

\begin{tabular}{|c|c|c|c|c|c|}
\hline & Position & $\mathrm{N}$ & Mean & Std. Deviation & Sig. (2-tailed) \\
\hline \multirow{2}{*}{ Transformational } & S41 & 60 & 3.93 & 0.39 & 0.003 \\
\cline { 2 - 6 } & S44-JUSA & 21 & 4.23 & 0.41 & \\
\hline
\end{tabular}

Table 8: Summary Statistics of Mann-Whitney $U$ Test on Transactional Leadership Style and Laissez-faire Leadership Style between Positions

\begin{tabular}{|c|c|c|c|c|c|}
\hline Item & $\begin{array}{c}\text { Mean Rank } \\
\text { (S41) }\end{array}$ & $\begin{array}{c}\text { Mean Rank } \\
\text { (S44-JUSA) }\end{array}$ & $\begin{array}{c}\text { Mann- } \\
\text { Whitney } \boldsymbol{U}\end{array}$ & Z-value & $\boldsymbol{p}$-value \\
\hline Transactional & 36.77 & 53.10 & 376.000 & -2.757 & 0.01 \\
\hline Laissez-faire & 40.28 & 43.05 & 587.000 & -.470 & 0.64 \\
\hline
\end{tabular}

The results of comparison as displayed in Table 8 show that significant difference $(p$ value lower than the recommended 0.05 level, $p=0.01$ ) is found on the position with regard to their transactional leadership style.

It appears that librarians with position of S44-JUSA give a slightly higher mean score (more positive on laissez faire leadership style) than those from S41 position, but this apparent difference is statistically not significant at the $5 \%$ significance level ( $p$ value $>0.05$ ). Therefore, it is concluded that on the average, the practise of laissezfaire styles does not differ between respondents of S41 and S44-JUSA.

\section{Differences between Experiences \\ Working}

It can be seen that the overall mean score of transformational leadership style for working experience, at 3.93 for respondents whose working experience was 10 years and below and 4.17 for those whose working experience was more than 11 years. These both differences are statistically significant at the 5\% level ( $p$ value<0.05) as presented in Table 9. Therefore, it is concluded that on the average, the transformational leadership style differs between respondents of working experience.

Table 9: Summary Statistics of $t$-test on Transformational Leadership Style between Working Experience

\begin{tabular}{|c|c|c|c|c|c|}
\hline & $\begin{array}{c}\text { Working } \\
\text { Experience }\end{array}$ & $\mathrm{N}$ & Mean & $\begin{array}{c}\text { Std. } \\
\text { Deviation }\end{array}$ & Sig. (2-tailed) \\
\hline Transformational & $\begin{array}{c}10 \text { years and } \\
\text { below }\end{array}$ & 55 & 3.93 & 0.40 & 0.02 \\
\cline { 2 - 6 } & Over 11 years & 26 & 4.17 & 0.41 & \\
\hline
\end{tabular}

Results of the statistical test are presented in Table 10. It can be seen that the overall mean score for the respondents who worked more than 11 years, at 49.12, is higher than the respondents who worked 10 years and below, at 37.16. This difference is statistically significant at the $5 \%$ level ( $p$-value $<0.05)$. Therefore, it is concluded that on the average, the transactional leadership style differs between respondents of working experience.
The results of comparison as displayed in Table 10 show that no significant difference ( $p$-value higher than the recommended 0.05 level, $p=0.69$ ) was found on the laissez-faire leadership style. Therefore, it is concluded that on the average, the laissez-faire leadership style does not differ between respondents of different work experience. 
Table 10: Summary Statistics of Mann-Whitney $U$ Test on Transactional Leadership Style and Laissez-faire Leadership Style between Working Experiences

\begin{tabular}{|c|c|c|c|c|c|}
\hline Item & $\begin{array}{c}\text { Mean Rank } \\
(10 \text { years and } \\
\text { below })\end{array}$ & $\begin{array}{c}\text { Mean Rank } \\
\text { (More than } \\
11 \text { years })\end{array}$ & $\begin{array}{c}\text { Mann- } \\
\text { Whitney } U\end{array}$ & Z-value & $p$-value \\
\hline Transactional & 37.16 & 49.12 & 504.000 & -2.150 & 0.03 \\
\hline Laissez-faire & 40.30 & 42.48 & 676.500 & -.395 & 0.69 \\
\hline
\end{tabular}

\section{Discussion and Conclusion}

This study had explored the types of leadership styles that academic librarians practised in university libraries and identified the differences in their leadership styles by gender, institution they work, age, position and working experience. As a conclusion, it was found that academic librarian seems to practise more transformational leadership style while exhibiting some characteristics of laissez-faire leadership style. Transactional leadership was minimally exhibited showing that it is not a preferred leadership style. The transactional leadership style showed significant difference among age groups. Furthermore, there was a significant difference among transformational leadership and transactional leadership between levels of positions and working experience of respondents. According to Tichny and Devanna (1990), these findings are a positive sign for academic libraries because most literature suggested the most effective and successful leaders practise transformational leadership style most of the time followed by some transactional leadership with a minimal practise of laissez-faire.

Transformational leadership contributes significant improvement to subordinates and organisational performance. To have maximum gain by practising transformational leadership style, professional education and training in libraries may place greater focus on leadership skills and learning that prepares young professionals for the softer side of organisational management. The librarians should apply a variety of leadership styles and practises based on the need and situation as they help in better problem solving and motivate subordinates to be proactive. Good leadership may give a positive direction to the use of human resources and brings out the best in a man. This study may give some ideas to develop new leadership styles, practitioners recognise their styles of leadership and the librarian may gain ideas and find other factors that can help them to engage with subordinates in the organisation.

\section{Acknowledgement}

This study was supported by Universiti Teknologi MARA (UiTM), Shah Alam, Malaysia. The researchers wished to thank UiTM and all respondents who had participated in the survey.

\section{References}

Baldoni, J. (2000). 180 Ways to Walk the Leadership Talk: The "How to" Handbook for Leaders at All Levels, Dallas, Texas, The Walk the Talk Company.

Bass, B. M., Avolio, B. J., Jung, D. I. \& Berson, Y. (2003). "Predicting Unit Performance by Assessing Transformational and Transactional Leadership," Journal of Applied Psychology 88 (2), 207-218.

Bohn, J. G. (2002). "The Relationship of Perceived Leadership Behaviors to Organizational Efficacy," Journal of Leadership \& Organizational Studies 9(2), 65-79.

Burns, J. M. (1978). Leadership, New York, Harper \& Row.

Dawson, D. (2002). "Developing Leadership Capacity within the Library Profession," 
[Paper presented at LIANZA Convention, 2002]. [Online], [Retrieved October 6, 2009]

http://www.lianza.org.nz/library/files/sto re018/dawson.pdf

de Jong, J. P. J. \& Hartog, D. N. D. (2007). “How Leaders Influence Employees' Innovative Behaviour," European Journal of Innovation Management 10(1), 41-64.

Fairholm, M. R. (2004). "A New Sciences Outline for Leadership Development," Leadership \& Organization Development Journal 25(4), 369-383.

Fatokun, J. O., Salaam, M. 0. \& Ajegbomogun, F. O. (2010). "The Influence of Leadership Style on the Performance of Subordinates in Nigerian Libraries," Library Philosophy and Practice,' 7(1), 7579.

Jalil, J. (2011). “The Relationship between Personality Traits, Internal Communication, Transformational Leadership and Sense of Urgency: A Mixed Method Study of Repo Malaysia," DBA Dissertation, Universiti Utara Malaysia.

Judge, T. A., Bono, J. E., Ilies, R. \& Gerhardt, M. W. (2002). "Personality and Leadership: A Qualitative and Quantitative Review," Journal of Applied Psychology 87(4), 765780.

Kent, T. W., Crotts, J. C. \& Aziz, A. (2001). "Four Factors of Transformational Leadership Behavior," Leadership \& Organization Development Journal 22(5), 221-229.

Lussier, R. N. \& Achua, C. F. (2007). 'Leadership,' Ohio, Thomson.

Marmaya, N. H., Hitman, M., Torsiman, N. N. \& Balakrishnan, B. (2011). 'Employee's Perception of Malaysian Managers' Leadership Styles and Organizational Commitment,' African Journal of Business Management 5(5), 1584-1588.

Snodgrass, J. \& Shachar, M. (2008). "Faculty Perceptions of Occupational Therapy Program Directors' Leadership Styles and
Outcomes of Leadership," Journal of Allied Health 37(4).

Tichny, N. M. \& Devanna, M. A. (1990). 'The Themes, the Protagonists, the Transformational Drama, the Transformational Leader,' John Wiley \& Sons Inc.

Wu, F. Y. \& Shiu, C. (2009). 'The Relationship between Leadership Styles and Foreign English Teachers Job Satisfaction in Adult English Cram Schools: Evidences in Taiwan,' The Journal of American Academy of Business, Cambridge $14(2)$. 